\title{
Long Peptide Vaccine 7
}

National Cancer Institute

\section{Source}

National Cancer Institute. Long Peptide Vaccine 7. NCI Thesaurus. Code C116067.

A peptide vaccine consisting of a combination of seven synthetic long peptides (SLPs), which are each about 30 amino acids in size, and derived from cancer-testis antigens (CTA) and melanocytic differentiation proteins (MDP), with potential immunostimulating and antitumor activities. Upon administration, long peptide vaccine 7 may stimulate the host immune system to mount a cytotoxic T-cell lymphocyte $(C T L)$ response ag ainst tumor cells expressing these peptides. CTA and MDP are overexpressed in a variety of cancer cell types. 